OPEN ACCESS

UNIVERSITY OF THE

WEST of SCOTLAND

UWS Academic Portal

\title{
Stay or go? - Roma, Brexit and European freedom of movement
}

Clark, Colin

Published in:

Scottish Affairs

DOI:

$10.3366 /$ scot.2020.0331

Published: 31/08/2020

Document Version

Peer reviewed version

Link to publication on the UWS Academic Portal

Citation for published version (APA):

Clark, C. (2020). Stay or go? - Roma, Brexit and European freedom of movement. Scottish Affairs, 29(3), 403418. https://doi.org/10.3366/scot.2020.0331

\section{General rights}

Copyright and moral rights for the publications made accessible in the UWS Academic Portal are retained by the authors and/or other copyright owners and it is a condition of accessing publications that users recognise and abide by the legal requirements associated with these rights.

Take down policy

If you believe that this document breaches copyright please contact pure@uws.ac.uk providing details, and we will remove access to the work immediately and investigate your claim. 


\title{
Stay or Go? - Roma, Brexit and European Freedom of Movement
}

\section{Colin Clark}

\begin{abstract}
The spectre of Brexit has raised issues of concern for Roma communities living and working in Scotland and other parts of the UK. The effective ending of freedom of movement has produced new uncertainties and insecurities for people living outside their EU countries of origin, especially for those who are racialised and stigmatised by 'hostile environment' policies. Brexit is best understood as both a process and effect of everyday bordering as well as a continuation of historically embedded structural divisions. This paper looks at everyday Roma life in Glasgow, via the work of the NGO Romano Lav (Roma Voice), to assess how Brexit is impacting on people's lives. Further, the paper examines how Scotland can best move forward in terms of independence and the European project. It is argued that a second independence referendum that gives full political independence to Scotland is the only way to secure future EU membership.
\end{abstract}

Key words: Brexit, Roma, migration, freedom of movement, Govanhill, Scotland

\section{Introduction}

The UK is leaving the European Union this evening. Those are words I had hoped never to have to write. Not least because an overwhelming majority of people in Scotland did not vote for this. Scotland is a proud European nation and I profoundly regret the UK's decision to leave. The European Union has brought together like-minded, independent nations on equal terms to work together for the mutual benefit of all our citizens.... I believe that Scotland has the right to choose its own future and that the best option for Scotland is to be an independent country, in the EU. In the meantime we will stand shoulder to shoulder with the rest of Europe around our shared values and interests.

- Nicola Sturgeon (First Minister's Letter to Europe, January $31^{\text {st }}, 2020$ )

Since at least June 24th, 2016 - the day after the European Union (EU) Referendum vote there has been a lot of public discussion in the United Kingdom (UK), and across other parts of Europe, about what will happen when 'Brexit' arrives. The debates have raged 24/7; often heated, contested and vexed. It has been a deeply uneasy and unsettling time, not least for the nearly four million EU citizens who live and work in the UK. However, some certainty has now arrived, with Brexit confirmed when the UK formally withdrew from the EU at $11 \mathrm{pm}$ on January $31^{\text {st }}, 2020$. We will now discover what the political realities and material consequences of the 'leave' decision in the EU Referendum will entail. As acknowledged in her open letter to Europe, the First Minister, Nicola Sturgeon, suggests this is not a situation that the majority of people in Scotland voted for and other options will 
now have to be examined to ensure that an independent Scotland might play an active role in the European project moving forwards.

The focus of this paper is an examination of the implications and consequences for freedom of movement of EU nationals, especially for Roma minority communities living and working in the UK, with a focused view from the geography of Govanhill in Glasgow. This paper traces how some Slovak, Polish and Romanian Roma families have started to think about, plan for, and respond to the possible futures that lie in wait for them and where they might find themselves, geographically, economically and socially. It also details some of the everyday concerns, anxieties and barriers that the communities are now facing in a postBrexit Britain. To 'stay or go' is a question asked by many Roma families in Scotland right now. The paper argues that Brexit can be understood in two broad ways: firstly, as a process and effect of prolonged, deeply rooted, maintained and normalised 'everyday bordering' that is defined by 'race', nationality and welfare conditionality as well as, secondly, a postBrexit strengthening of exisiting social divisions along the racialised practices established by such bordering.

The paper also looks at the wider 'place' of Scotland in Europe and how it positions itself as part of the 'European project'. During the Brexit debates, we witnessed elements of both civic and ethnic nationalism being embraced, especially by the Scottish National Party (SNP), to illustrate supposed political differences with England. The position of this paper is quite clear: it will be argued that in order to try and protect freedom of movement after Brexit Scotland must: a) secure its political independence from the rest of the UK and b) negotiate a secure place back in the heart of the European project as a full and independent member of the EU.

How did it come to all this? Are we destined for a future of cultural and political isolation, economic impoverishment and intellectual harm if Scotland does not seek independence? The Irish journalist and commentator Fintan O'Toole (2018) argued that Brexit has starkly illustrated how lies have become truth, the oppressor now presents as the oppressed and an openly populist and xenophobic English nationalism is a force that now dares to speak its name. These factors all need to be considered for how they impact on those individuals and families at the sharp end of a divided Brexit politics - what of Roma and their freedom of movement?

\section{Freedom of Movement and Brexit}

What is meant by 'freedom of movement', in the European context, and what is its relationship to Brexit? In its broadest sense, freedom of movement, or the rights to mobility and travel, can be regarded as a human rights concept and practice that enables individuals and families to move from one location to another within a given country or territory and to also leave that country and then return to it (Mindus, 2017). Such a right to mobility is not just confined to travel for short visits but may include brief or extended periods of residence as well as working in different territories with associated, often limited, social and economic rights (Bruzelius, 2019). Freedom of movement, for example, is enshrined in Article 13 of the Universal Declaration of Human Rights although it is, in practice, restricted in several 
ways by Governments - such as via immigration and bordering regimes, as well as public health and safety orders (Benson, 2019).

In a European context, via the structures and agencies of the European Union, freedom of movement takes on a very particular form and meaning, and this carries with it an associated set of differing public attitudes: it can be seen as both an 'opportunity' and a 'threat' depending on who you ask, and how you ask them (Vasilopoulou and Talving, 2019). For residents within member states of the EU, their citizenship entitles them to free movement within EU internal borders. Such a right was established via a succession of Treaties and Directives such as the Treaty on the Functioning of the European Union (1957), Treaty on European Union (better known as The Maastricht Treaty) (1992) as well as the European Parliament and Council Directive 2004/38/EC (2004). In short, at least in theory, freedom of movement has been viewed as the 'cornerstone' of Union citizenship. However, even the European Parliament acknowledges this is not unproblematic: 'Notwithstanding the importance of this right, substantial implementation obstacles persist, 10 years after the deadline for implementation of the Directive.' (Marzocchi, 2020: np). This acknowledgment of the 'obstacles' or difficulties in securing freedom of movement within the internal borders of the EU is intensified when assessing how Roma families, and other migrant, marginalised or stigmatised groups, have sought to operationalise their formal and substantive rights to mobility - the 'gears' of EU citizenship can work in unhelpful ways (Juverdeanu, 2019).

As Sardelić (2019: 139) argues, EU freedom of movement should be defended on a 'normative as well as practical level'. However, this 'freedom' as a legal right can fall short when examined as a substantive social justice reality for certain minority ethnic groups trying to move across European borders. Indeed, the debates around Brexit have illustrated that such freedoms need to be viewed outside just a European territory perspective and placed within a broader transnational, global setting. This is especially true when examining the situation of Roma communities and their engagement with travel and mobility within, and outside, European borders. Indeed, a recent study by Tileaga, Aldridge and Popoviciu (2019) has illustrated that from a UK perspective there are a number of 'drivers and challenges' when looking at Roma migration within the EU, not least issues of media and political representation where such groups are regarded as 'welfare tourists' or 'abusing' EU freedom of movement 'privileges' (Kostka, 2019). In an immediate and longer-term postBrexit world, it is likely that such 'challenges' on human rights will be pushed to the boundaries.

It has been suggested that the ending of freedom of movement after Brexit is 'reckless' and will contribute to an intensification of the 'hostile environment' policies that former Home Secretary (2010-2016) and Prime Minister (2016-2019) Theresa May promoted during her respective tenure of those two offices, whether by design, accident or default (Burrell and Schweyher (2019). In the case of migrants from across central and Eastern Europe (CEE) living in Britain, including Roma families, there appears to be evidence to show a hardening of already ingrained and damaging attitudes. Practices of everyday 'welfare bordering' and a range of measures to add unnecessary complexity to family life via policies arising from a desire to inculcate a 'hostile environment' are present and a reality for CEE and other migrants - even those with the supposed 'protection' of 'whiteness', such as Polish migrants 
(Guentner, Lukes, Stanton, Vollmer and Wilding, 2016). Of course, the material and psychological impact has been felt by some communities more than others, dependent on respective socio-economic situations. Welfare conditionality aspects, as well as degrees of 'settlement' across all areas of life, including access to regular work, health and well-being, children being in school and other indicators are foregrounded here (Dwyer, Scullion, Jones and Stewart, 2019).

In a post-Brexit Britain, aspects of the 'four freedoms' - the free movement of goods, capital, services and labour across the EU - will be redundant and expendable. This is especially true for the movement of labour - that is, people - and the attack on freedom of movement cuts across conceptual, legal and political terrains. Floris de Witte (2019) has argued that freedom of movement should be defended and is resolutely tied to questions of EU citizenship. Indeed, such a defence can be positioned more broadly in relation to how the individual is connected or not connected to the nation state and how we think of justice in relation to democracy. A defence of free movement, for example, can assist in detaching us from the quirks of 'community of fate' that serves to buttress exclusion and securitise everyday bordering (Menéndez and Olsen, 2020). Further, freedom of movement has been further problematised in the post-2008 financial climate. A politicised connection was made between preserving a 'sustainable' welfare state for (immobile) citizens and trying to dissuade or exclude (mobile) migrants who were intent on moving across internal EU borders and settling and accessing support and services in their chosen destination state (Lamour, 2019). The next section looks at exactly these matters in relation to Roma communities who have settled in Glasgow. How have their lives and livelihoods been impacted by Brexit? What does the future hold?

\section{Brexit and Roma Life in Glasgow}

As I have documented elsewhere, Roma families and communities from several central and Eastern European countries have left their countries of origin and made Glasgow their 'new' home for many years now (Clark, 2014; 2016; 2018a). Although there are clear historical patterns of Roma migration and settlement prior to the mid-2000s, mainly as asylumseekers and refugees, there was a rise in numbers travelling across European borders following periods of EU enlargement in 2004 and in 2007. The reasons for such family movement to different parts of Britain are varied and complex and cannot be reduced to just one single aspect or dimension (Smith, 2018). However, several common themes are apparent, including insecurity and a fundamental lack of trust and faith in the institutions of CEE home states, as well as a firm belief that a permanent or semi-permanent move 'West' will give their children a chance to thrive and receive the mainstream education they deserve, rather than being segregated into 'special classes' (Sime, Fassetta and McClung, 2018). Indeed, in this way Roma families are no different to most other migrant communities who enact their mobility to escape racism and discrimination in their countries of origin, as well as embracing new opportunities and challenges in destination countries. At face value, there is a high degree of sameness and familiarity, rather than uniqueness, in approaches to migration and settlement undertaken by Roma and other EU nationals. It is never something that is undertaken lightly or without due consideration; Roma mobility tends to be planned, strategic and deliberate - as in the case of Romanian Roma who have travelled West after EU accession (Matras and Leggio, 2017). This is a familiar narrative 
across the field of migration studies more broadly, and it is equally apparent in the case of Glasgow and the Roma families who have moved to the city (Guma, 2019).

Nonetheless, it has been argued that Roma migration in Europe has aspects to it that can perhaps best be viewed and addressed via the critical lens of 'race', neoliberalism and AntiGypsyism (Kóczé, 2018). For example, by examining public, academic, policy and political debates in Italy and France, Kóczé argues that racialised discourses and broader neoliberal social and political forces seek to deliberately identify Roma as 'other' and to normalise their exclusion and isolation through a means of biopolitically securitising borders and tightening access to state resources (van Baar, Ivasiuc and Kreide, 2019). Such a critical lens has also been employed in the local context of Glasgow via the recent work of Mullen (2018) who argues that the media and political coverage of the communities reflects outsider 'fears' of the location (Govanhill) as much as it does about the community itself (Roma). Such 'place-based racialisation' can lead to an entirely unhelpful situation whereby the complex issues and day-to-day challenges faced by families in a bounded local territory metamorphosise into problems of and with the community itself - 'the Roma problem'. In this sense, underlying spatial and structural issues connected to noise, dirt, overcrowding, infestation and the like are attached - with subjective and racialised blame - to a specific stigmatized migrant community rather than being viewed as issues that have a deep history and an overarching attachment to the space, geography and inhabitants more generally (Wacquant, 2007).

What of everyday life for Roma families and how has Brexit impacted on the communities in Glasgow? Outside of my University 'day job' I am a Trustee and volunteer for Romano Lav (Roma Voice). This small, grassroots charity was established by Marcela Adamova and other Roma community members in Govanhill back in 2011, mainly as a focal point for promoting Roma justice, social inclusion and intercultural dialogue in the local area and across Scotland (Romano Lav, 2019a). It is in this context and through various local meetings, events and engagements that a topic of conversation even before the EU Referendum in 2016 was Brexit. Indeed, it would be more accurate to say that issues of belonging, identity, citizenship - that is, staying or having to leave Scotland - were first raised during the earlier Scottish Independence Referendum in September 2014. These conversations at public events illustrated that contrary to popular belief, members of the Roma community were aware, engaged and concerned with political events in Scotland and wanted to be heard. As an example, Penha (2014) has captured the essence of what was discussed at two meetings in August 2014 at Govanhill Baths where younger and older members of the Slovakian, Romanian and Polish Roma communities talked about their feelings on Scottish Independence and the then forthcoming Referendum. On one hand Francisca (age 16 from Slovakia) said that 'I will vote Yes because maybe it will be better for Scotland and will arise more jobs ' whereas Ronaldo (age 18 from Slovakia) said he would vote no as 'I don't know what will happen after. I am scared.' The meetings demonstrated that political debate was happening and information about voter registration was being shared and circulating about the Referendum, as well as the potential implications of both Yes and No vote outcomes.

Of course, a major difference between the Scottish Independence Referendum in September 2014 and the EU Referendum held in June 2016 was that in the latter Referendum the vast majority of Roma in Scotland, like most other European migrant 
communities, were not entitled to vote. In various Romano Lav meetings in the run-up to June 2016, I recall trying to explain the distinction between the two Referendums to community members in terms of who could and who could not take part in the forthcoming Brexit vote. This was not an easy task and the apparent inequity was sensed and felt by many people who were immediately worried about what might happen if the UK left the EU, both in immediate and practical terms, as well as a deep-rooted fear over increased racism, hostility and overt prejudice towards European migrants. As McKenna (2019) argues, Brexit and xenophobia are inextricably intertwined and not issues that can be ignored by Scotland. He specifically mentions the Roma communities in Glasgow and urges support and solidarity in the face of an anti-migrant backlash. Such fears and uncertainties over the future have also been discussed by Vickers (2019) in a broader British context and notes the work of charities, such as the Roma Support Group in London, who report that numerous Roma individuals and families are encountering problems with their applications for 'Settled Status' in the UK due to a lack of appropriate documentation, English language issues, digital illiteracy and access to suitable technology (Shallice, 2019).

To date, most Roma families are still playing a waiting game in Glasgow and across Britain more generally. The recent ethnographic work of Rachel Humphris has vividly documented the impact that such stasis, especially with the Home Office and other agencies of the welfare state, can have on Roma family life and the disruptive aspects this causes to lives and livelihoods (Humphris, 2019). Indeed, as far back as October 2016, immediately after the EU referendum vote, it was noted by an Institute for Public Policy Research report that a 'triple whammy' of challenges would be faced by Roma communities moving forwards (Morris, 2016). These challenges included:

1, legal uncertainty in Britain regarding rights of residency;

2 , vulnerability and stigma as minority group facing persecution and discrimination in Britain, in terms of being victims of a notable spike in hate crime (Albert, 2019);

3, with the ending of EU funding for Roma integration even worse financial destitution was most likely.

Fast forward from 2016 to 2020 and these predictions have been borne out. The IPPR study was also useful in the sense that it focused on the important role for Local Authorities in terms of resolving some of the aforementioned challenges at an early stage, as part of a broader mainstreamed approach to mitigating the impact of Brexit in local communities (Morris, 2016). It is highly debatable if Local Authorities were effective in playing a preventative role in terms of post-Brexit contingency planning, given austerity cuts and everyday budget pressures (MacLeod and Jones, 2018).

Via the grassroots work of Romano Lav and research evidence gathered from Govanhill, one example illustrates some of the stark issues that are playing out regarding stigmatisation, mobility, residency rights and removals from Britain (Romano Lav, 2019b). In its submission to the Scottish Government Equal Opportunities Committee, the charity noted a disturbing trend regarding the Home Office adopting processes of so-called 'voluntary return' towards, specifically, Romanian Roma. A spike in removals, immigration patrols and other forms of 
Police monitoring and surveillance tactics in Govanhill during 2017-2018 led Romano Lav to lay charges of racial profiling and illegal enforced removals against the Home Office. It was discovered that these tactics were formalised via 'Operation Mighty' as it was known (Butterly, 2018). Welfare rights workers, community organisations and local residents in Govanhill noticed this activity by the Home Office, the Police and other agencies and reported concerns to Romano Lav, who had also received direct reports from the families of Romanian Roma who had been subjected to such treatment at Brand Street Immigration Centre and questioned, under caution, without a solicitor or interpreter present, about their immigration, employment and benefits status (Stewart, 2017). Further, Romano Lav received reports of detentions of Romanian Roma at Dungavel, often women picked up whilst resource gathering ('begging') in Glasgow city centre, as well as Romanian Roma being denied entry to Britain at Scottish airports, especially if unable to produce written employment contracts, in itself not a reason to deny entry (Romano Lav, 2019b). This situation led to fears amongst the Romanian Roma community about their future in Glasgow.

\section{Brexit, Scotland and a European Future?}

...Scotland is your home, you are welcome here, and you are valued. You play a crucial role in Scotland's economy and public services. You are a vital part of Scotland not just for the skills and talent you bring to our country but also the diversity and richness you bring to our culture and communities.

- Nicola Sturgeon (First Minister's Letter to EU Citizens, April $5^{\text {th }}, 2019$ )

Although $62 \%$ of EU referendum voters in Scotland wanted to remain in the EU, this fact made no difference to the UK eventually leaving, even with an SNP surge in both the European elections and UK General Election held in 2019 (McDougall, 2019). So, what role will Scotland now play in a post-Brexit UK and Europe? How will Scotland ensure that marginalised communities, such as the Roma, feel safe and secure moving forwards? Given Brexit only formally happened on January $31^{\text {st }}, 2020$ it is too early to speculate on this. However, there is some evidence to suggest that Scottish independence - rejected by $55 \%$ of voters in 2014 - might now be a (majority) possibility. To begin with, in her open letter of April $5^{\text {th }}, 2019$ addressed to EU citizens living and working in Scotland, Nicola Sturgeon was clear that such individuals and families are welcomed and valued in their new home. This letter followed a previous letter published on July $6^{\text {th }}, 2016$ where the First Minister had also discussed the result of the EU referendum and the uncertainty and worry it would understandably bring to EU citizens who had come to Scotland with at least some hope of a secure future (Sturgeon, 2016). However, it must be said that public political reassurances from the First Minister are one thing, but what can practically happen to guarantee such words and transform them into accountable socio-legal and policy actions, especially when the actions at Holyrood are constrained by Westminster?

In terms of evidence regarding themes of uncertainty and security, Godin and Sigona (2019) have suggested that EU families regard themselves as being made to feel more welcome in Scotland when compared to other parts of the UK, as part of a 'national 
community' North of the border. Interestingly, many of the respondents and participants in focus groups organised by the researchers also reported Scotland to 'feel' like a less 'hostile environment' than England and a safer place to raise children and plan a future, inspired by the letters previously mentioned authored by the First Minister. These comments by Nicola Sturgeon left a 'positive and lasting mark' for respondents (Godin and Sigona, 2019). This work dovetails, but also contrasts, with the work of Naomi Tyrrell and colleagues who have recently examined the experiences of young people from Central and Eastern Europe living in Britain who have encountered overt racism and prejudice following the Brexit result, including interviewees in Scotland (Tyrrell, Sime, Kelly and McMellon, 2019). In many ways, it is the 'what next?' question that dominates the discussion here amongst EU citizens in Scotland and the indications are that perhaps the era of 'wait and see', the norm between the period 2016 and 2020, is now coming to an end. Decisions about whether to 'stay or go' need to be made soon, not least in relation to applying for Settled Status before June 30, 2021 when the scheme officially closes.

Politically, as one would expect, things are shifting quickly. A recent intervention from the new EU ambassador to the UK, João Vale de Almeida, specifically mentioned the situation of the Roma, as well as prisoners, older people and other groups "outside of the mainstream" who will require additional support to remain in the UK after Brexit (Boffey, 2020). This is especially relevant in Scotland as the First Minister's constituency is in the Govanhill area of Glasgow, where the majority of Roma in Scotland live. Occasionally, in the recent past, this connection between the First Minister and her constituency area of Govanhill has been luridly exploited by certain newspapers and the Roma have been collectively used as a means to target Sturgeon and query broader SNP governance and 'competency to rule' (see, for example, the reporting of The Times, via Horne, 2017). Vale de Almeida raised the scenario of what happens to those individuals who, for whatever reason, do not apply for settled status before the June 30, 2021 deadline. Although initially a hardline view was taken by some senior figures in the Westminster Government, such as Brandon Lewis when he was Security Minister who suggested deportations would occur soon after the deadline, the Home Office has since softened its current position suggesting more flexibility for delayed or late applications (Boffey, 2020). However, positions shift rapidly and given the overwhelming result of 2019 UK General Election this softer position towards 'at risk' EU populations, including Roma, cannot be guaranteed by a dominant Conservative Party.

\section{Conclusion}

To 'stay or go' has been one of the main topics of conversation in Govanhill for the last four years amongst the Roma families staying in the area. This has not been a straightforward or easy process to discuss with stress and anxiety evident. Family life has been disrupted, no doubt, but life goes on and the day-to-day activities of earning a living, going to school and looking after the family continues in a fragile and heightened state of uncertainty. In this sense, the situation of the Roma is not that different from other EU nationalities who are also waiting to see what will happen next and what they will do. This paper has reviewed the situation of Roma communities in Scotland who are currently living under the spectre of Brexit. A waiting game, until recently, has been played by families already living in Scotland. Through the committed work of Romano Lav, we know that some extended families have opted to enact their agency and return to their former homes in Slovakia, Romania, Poland, 
Bulgaria and other central and Eastern European states. This is no surprise. It is difficult, psychologically speaking, to stay somewhere if you are made to feel unwelcome on a dayto-day basis (Guma and Jones, 2019). The pressure and tensions can build up, it is easier just to pack up and leave. In a sense, it is a form of reclaiming power to decide to leave yourselves, as a family, rather than waiting for a knock on the door and be deported by the authorities. Indeed, despite the overarching narrative and mythology, we know that racism exists in Scotland and that it exists in Govanhill, including evidence of it being directed towards the Roma (Clark, 2018b).

But it isn't just a question of leaving. Other families, since the EU referendum in 2016, have continued to arrive in Scotland - the message from family members already established here has been to 'get in quick' before the borders are closed and freedom of movement across the EU is a distant memory. We have noted earlier in the discussion some issues in this regard for Romanian Roma in particular, struggling to get past immigration control at Glasgow airport ('Operation Mighty') and others still, already in Scotland, being held at Dungavel and subjected to 'voluntary return'. For most families, it is still a case of trying to gather the required evidence - from over five years at least - to apply for settled status and grappling with an App that is not as user-friendly as the government contends. Applying to stay in a country you have called home for some years has not been easy on many levels, emotionally, practically, technologically, as the Roma Support Group in London has evidenced (Godin and Calin Bica, 2019). It was argued in the paper that Brexit in many ways represented a sense of continuity; a process involving forms of racialised 'everyday bordering' that families have become used to. However, such bordering will likely worsen already entrenched social divisions in post-Brexit realities and under a new immigration system.

Ultimately, what price is to be paid for 'Brexit meaning Brexit'? This paper has touched on issues relating to freedom of movement and how this is impacted by the UK's withdrawal from the EU. In short, this freedom has ended, effectively, and we are facing a new economic and political reality that is unknown and unfamiliar: the unveiling of a new pointsbased immigration regime was announced by the government in February 2020 (Kettle, 2020). Politically, the place of Scotland in relation to Europe after Brexit has also been examined in this paper. It is suggested that in order to retain freedom of movement, and play a role in the European project, a second Scottish independence referendum is essential (Dickie, 2020). There has been a clear shift, politically speaking, and this is a timely moment to consider the options and steer the agenda towards a divorce from the UK and independent membership of the EU. Indeed, recent polls place support for Scottish Independence at $52 \%$ in favour of Yes (Learmonth, 2020). As Nicola Sturgeon suggested in her January 2020 letter to Europe, hopefully 'a light has been left on for' Scotland by the EU and this should be welcomed by the people of Scotland, including EU citizens calling Scotland their home. The protection of freedom of movement and EU membership, as well as offering a safe place to live for Roma communities, is now explicitly tied to Scotland's future as an independent country.

\section{References}


Albert, G. (2019) 'Petr Torák: Hate crimes spiked in the UK after the Brexit referendum, what will the elections bring?', Romea.cz, http://www.romea.cz/en/news/world/petr-torakhate-crimes-spiked-in-the-uk-after-the-brexit-referendum-what-will-the-elections-bring (accessed 02-03-20)

Benson, M. (2019) 'Brexit and the Classed Politics of Bordering: The British in France and European Belongings'. Sociology. https://doi.org/10.1177/0038038519885300

Boffey, D. (2020) 'EU vows to help nationals 'outside the mainstream' stay in the UK', The Observer, March 1 $1^{\text {st }}$. https://www.theguardian.com/uk-news/2020/mar/01/eu-scheme-tohelp-roma-prisoners-stay-uk-after-brexit (accessed 03-03-20).

Bruzelius, C. (2019). 'Freedom of movement, social rights and residence-based conditionality in the European Union'. Journal of European Social Policy, 29(1), 70-83. https://doi.org/10.1177/0958928718756262

Burrell, K. and Schweyher, M. (2019) 'Conditional citizens and hostile environments: Polish migrants in pre-Brexit Britain', Geoforum, Volume 106, Pages 193-201, https://doi.org/10.1016/i.geoforum.2019.08.014

Butterly, M. (2018) 'Operation Mighty, 2017-2018 - freedom of information request to the Scottish Government', What Do They Know, https://www.whatdotheyknow.com/request/operation mighty 2 (accessed 02-03-20).

Clark, C. (2014) 'Glasgow's Ellis Island? The integration and stigmatisation of Govanhill's Roma population'. People, Place and Policy, 8(1), 34-50.

https://doi.org/10.3351/ppp.0008.0001.0004

Clark, C. (2016) 'Integration, exclusion and the moral 'othering' of Roma communities in Britain'. In V. Cree, G. Clapton, \& M. Smith (Eds.), Revisiting Moral Panics. Bristol: Policy Press.

Clark, C. (2018a) "For work, we came here to find work.": migrant Roma employment and the labour of language. In P. Beresford and S. Carr (Eds.), Social Policy First-Hand: An International Introduction to Participatory Social Welfare. Bristol: Policy Press.

Clark, C. (2018b) 'Sites, welfare and 'barefoot begging': Roma and Gypsy/Traveller experiences of racism in Scotland', in Davidson, N., Liinpää, M., McBride, M., and Virdee, S. (eds.) No Problem Here: understanding racism in Scotland, Edinburgh: Luath Press.

De Witte F. (2019) 'Freedom of Movement Needs to Be Defended as the Core of EU Citizenship'. In: Bauböck R. (eds.) Debating European Citizenship. IMISCOE Research Series. Springer, Cham.

Dickie, M. (2020) 'Free movement in Scotland for EU citizens wins support', The Financial Times, 03-03-20. https://www.ft.com/content/d203ea68-5c89-11ea-b0ab-339c2307bcd4 (accessed 04-03-20) 
Dwyer, P., Scullion, L., Jones, K. and Stewart, A. (2019) 'The impact of conditionality on the welfare rights of EU migrants in the UK', Policy \& Politics, Volume 47, Number 1, January 2019, pp. 133-150, DOI: https://doi.org/10.1332/030557318X15296527346800

Godin, M. and Calin Bica, M. (2019) "'It took 2 hours and one third didn't get through": piloting the settled status application with Roma migrants', Guest Blog, Roma Support Group London. January $21^{\text {st }}$. https://eurochildren.info/2019/01/21/it-took-2-hours-and-onethird-didnt-get-through-piloting-the-settled-status-application-with-roma-migrants/ (accessed 03-03-20)

Godin, M. and Sigona, N. (2019) 'EU families feel more welcome in Scotland than they do in the rest of the UK', LSE European Politics and Policy Blog, October $10^{\text {th }}$.

https://blogs.Ise.ac.uk/europpblog/2019/10/10/eu-families-feel-more-welcome-inscotland-than-they-do-in-the-rest-of-the-uk/ (accessed 03-03-20).

Guentner, S., Lukes, S., Stanton, R., Vollmer, B. A., \& Wilding, J. (2016). 'Bordering practices in the UK welfare system'. Critical Social Policy, 36(3), 391-411.

https://doi.org/10.1177/0261018315622609

Guma, T. (2019) 'The making of a 'risk population': categorisations of Roma and ethnic boundary-making among Czech- and Slovak-speaking migrants in Glasgow', Identities, 26:6, 668-687, DOI: 10.1080/1070289X.2018.1441690

Guma, T. and Jones, R. D. (2019) “"Where are we going to go now?" European Union migrants' experiences of hostility, anxiety, and (non-) belonging during Brexit', Population, Space and Place, 25(1). https://doi.org/10.1002/psp.2198

Horne, M. (2017) 'Children sold for sex on streets of Govanhill', The Times, November $17^{\text {th }}$. https://www.thetimes.co.uk/article/children-sold-for-sex-on-streets-of-govanhill-db2gptfgx (accessed 03-03-20)

Humphris, R. (2019) Home-Land: Romanian Roma, Domestic Spaces and the State, Bristol: Bristol University Press.

Juverdeanu, C. (2019) 'The different gears of EU citizenship', Journal of Ethnic and Migration Studies, DOI: 10.1080/1369183X.2019.1632697

Kettle, M. (2020) 'The new Tory immigration system won't work - except at the ballot box', The Guardian, February 19.

https://www.theguardian.com/commentisfree/2020/feb/19/tory-points-basedimmigration-low-skilled-workers-politics-economy (accessed 04-03-20)

Kostka J. (2019) 'The Migrating Poor: Romanian Roma Under Social Authoritarianism in Poland'. In: Magazzini T., Piemontese S. (eds.) Constructing Roma Migrants. IMISCOE Research Series. Springer, Cham. 
Kóczé, A. (2018) 'Race, migration and neoliberalism: distorted notions of Romani migration in European public discourses', Social Identities, 24:4, 459-473, DOI:

$10.1080 / 13504630.2017 .1335827$

Lamour, C. (2019) 'Schengen Europe in State-national Museums: Immobile Europeans, Immobilized "Others" and the Meaning of Borders', Journal of Borderlands Studies, 34:3, 343-359, DOI: 10.1080/08865655.2017.1340849

Learmonth, A. (2020) 'Massive surge for Yes as new poll puts independence vote at 52\%', The National, February $3^{\text {rd }}$. https://www.thenational.scot/politics/18208123.new-pollshows-52-voters-support-indyref2-scotland/ (accessed 03-03-20)

MacLeod, G., and Jones, M. (2018) 'Explaining 'Brexit capital': uneven development and the austerity state', Space and Polity, 22:2, 111-136, DOI: 10.1080/13562576.2018.1535272

McDougall, W. (2019) 'SNP surge in European elections has major implications for a second Scottish independence referendum', The Conversation, June $3^{\text {rd }}$.

http://theconversation.com/snp-surge-in-european-elections-has-major-implications-for-asecond-independence-referendum-117998 (accessed 03-03-20).

McKenna, K. (2019) 'Brexit's impact on xenophobia is an issue we cannot ignore in Scotland', The National, April 17 ${ }^{\text {th }}$, https://www.thenational.scot/news/17578272.brexitsimpact-on-xenophobia-is-an-issue-we-cannot-ignore-in-scotland/ (accessed 28-02-20)

Marzocchi, O. (2020) Free Movement of Persons, Fact Sheets on the European Union. Brussels: European Parliament. https://www.europarl.europa.eu/ftu/pdf/en/FTU 4.1.3.pdf (accessed 28-02-20)

Matras, Y., and Leggio, D. (eds) (2017) Open Borders, Unlocked Cultures: Romanian Roma Migrants in Western Europe. London: Routledge.

Menéndez A.J., Olsen E.D.H. (2020) 'The Concept and the Conception of Citizenship'. In: Challenging European Citizenship. Palgrave Studies in European Union Politics. Palgrave Pivot, Cham.

Mindus, P. (2017) European Citizenship after Brexit: Freedom of Movement and Rights of Residence. Palgrave Pivot, Cham.

Morris, M. (2016) Roma Communities and Brexit: Integrating and Empowering Roma in the UK, October 2016, London: IPPR. https://www.ippr.org/publications/roma-communitiesand-brexit (accessed 02-03-20)

Mullen, A. (2018) "Race', place and territorial stigmatisation: the construction of Roma migrants in and through Govanhill, Scotland'. In: Devine, T. M. and McCarthy, A. (eds.) New Scots: Scotland's Immigrant Communities Since 1945. Edinburgh University Press: Edinburgh. 
O'Toole, F. (2018) Heroic Failure: Brexit and the Politics of Pain, New York: Apollo Publishers.

Penha, J. (2014) 'Yes or No? The Roma Opinion (Scottish Independence Referendum)', Blog post, Govanhill Voice, https://govanhillvoice.wordpress.com/2014/09/18/142/ (accessed 28-02-20).

Romano Lav (2019a) Annual Report, 2017-2018, Dundee: Office of the Scottish Charity Regulator (OSCR) https://www.oscr.org.uk/AccountsDocument/Download/195857 (accessed 28-02-20)

Romano Lav (2019b) Unlawful Deportation of Romanian Roma and Immigration Enforcement: briefing paper for elected members, Submission to the Scottish Government Equal Opportunities Committee. Romano Lav: Glasgow.

https://www.parliament.scot/S5 Equal_Opps/Submission from_Friends of Romano Lav.p df (accessed 02-03-20)

Sardelić J. (2019) 'Reading Too Much and Too Little into the Matter? Latent Limits and Potentials of EU Freedom of Movement.' In: Bauböck R. (eds.) Debating European Citizenship. IMISCOE Research Series. Springer, Cham.

Shallice, A. (2019) Roma Civil Monitor Report - Year 3: Roma and Brexit, December 2019, Roma Support Group, London. https://www.romasupportgroup.org.uk/our-research.html (accessed 01-03-20)

Sime, D., Fassetta, G. and McClung, M. (2018) 'It's good enough that our children are accepted': Roma mothers' views of children's education post migration, British Journal of Sociology of Education, 39:3, 316-332, DOI: 10.1080/01425692.2017.1343125

Smith, D. (2018) 'Roma migration, anti-migrant sentiment and social integration: A case study in South-east England'. Local Economy, 33(2), 187-206.

https://doi.org/10.1177/0269094218766456

Stewart, C. (2017) 'Roma arriving in Scotland being 'unfairly targeted', The Herald, December $12^{\text {th }}$. https://www.heraldscotland.com/news/15715277.roma-arriving-inscotland-being-targeted-unfairly/ (accessed 02-03-20)

Sturgeon, N. (2016). Letter from the First Minister to EU Citizens in Scotland, Edinburgh: Scottish Government. https://www.gov.scot/publications/letter-from-first-minister-to-eucitizens-in-scotland/ (accessed 28-02-20)

Sturgeon, N. (2019) First Minister's letter to EU citizens in Scotland, Edinburgh: Scottish Government. https://www.gov.scot/publications/first-ministers-letter-to-eu-citizens-inscotland/ (accessed 28-02-20)

Tileaga, C., Aldridge, J. and Popoviciu, S. (2019) Drivers of Roma migration: Understanding migration in politically uncertain times. Loughborough University and the Ruhama Foundation. 
Tyrrell, N., Sime, D., Kelly, C., and McMellon, C. (2019) 'Belonging in Brexit Britain: Central and Eastern European 1.5 generation young people's experiences', Population, Space and Place, 25(1). https://doi.org/10.1002/psp.2205

van Baar H., Ivasiuc A., Kreide R. (2019) 'The European Roma and Their Securitization: Contexts, Junctures, Challenges'. In: van Baar H., Ivasiuc A., Kreide R. (eds) The Securitization of the Roma in Europe. Human Rights Interventions. Palgrave Macmillan, Cham.

Vasilopoulou, S. and Talving, L. (2019) 'Opportunity or threat? Public attitudes towards EU freedom of movement', Journal of European Public Policy, 26:6, 805-823, DOI: 10.1080/13501763.2018.1497075

Vickers, H. (2019) 'Brexit could bring 'a new Windrush' for Roma', The Bristol Cable, January $29^{\text {th }}$, https://thebristolcable.org/2019/01/brexit-could-bring-a-new-windrush-for-roma/ (accessed 28-02-20)

Wacquant, L. 'Territorial stigmatization in the age of advanced marginality', Thesis Eleven, 91:1 (2007), pp. 66-77. 